\title{
Arecoline induced disruption of expression and localization of the tight junctional protein ZO-1 is dependent on the HER 2 expression in human endometrial Ishikawa cells
}

\author{
Sarbani Giri ${ }^{1}, 2$, Kevin M Poindexter ${ }^{1}$, Shyam N Sundar ${ }^{1}$ and Gary L Firestone*1
}

\begin{abstract}
Background: Approximately 600 million people chew Betel nut, making this practice the fourth most popular oral habit in the world. Arecoline, the major alkaloid present in betel nut is one of the causative agents for precancerous lesions and several cancers of mouth among those who chew betel nut. Arecoline can be detected in the human embryonic tissue and is correlated to low birth weight of newborns whose mothers chew betel nut during pregnancy, suggesting that arecoline can induce many systemic effects. However, few reports exist as to the effects of arecoline in human tissues other than oral cancer cell lines. Furthermore, in any system, virtually nothing is known about the cellular effects of arecoline treatment on membrane associated signaling components of human cancer cells.

Results: Using the human Ishikawa endometrial cancer cell line, we investigated the effects of arecoline on expression, localization and functional connections between the ZO-1 tight junction protein and the HER2 EGF receptor family member. Treatment of Ishikawa cells with arecoline coordinately down-regulated expression of both ZO-1 and HER2 protein and transcripts in a dose dependent manner. Biochemical fractionation of cells as well as indirect immunofluorescence revealed that arecoline disrupted the localization of ZO-1 to the junctional complex at the cell periphery. Compared to control transfected cells, ectopic expression of exogenous HER2 prevented the arecoline mediated down-regulation of ZO-1 expression and restored the localization of ZO-1 to the cell periphery. Furthermore, treatment with dexamethasone, a synthetic glucocorticoid reported to up-regulate expression of HER2 in Ishikawa cells, precluded arecoline from down-regulating ZO-1 expression and disrupting ZO-1 localization.

Conclusion: Arecoline is known to induce precancerous lesions and cancer in the oral cavity of betel nut users. The arecoline down-regulation of ZO-1 expression and subcellular distribution suggests that arecoline potentially disrupts cell-cell interactions mediated by ZO-1, which may play a role in arecoline-mediated carcinogenesis. Furthermore, our study has uncovered the dependency of ZO-1 localization and expression on HER2 expression, which has therefore established a new cellular link between HER2 mediated signaling and apical junction formation involving ZO-1.
\end{abstract}

\section{Background}

Areca nut (Areca catechu Linn) chewing in the form of betel quid is popular in southeast Asian countries and plays a major role in the pathogenesis of precancerous lesions and several cancer of the oral cavity, including precancerous lesions such as leukoplakia and oral submucous fibrosis $[1,2]$. Epidemiological studies also indicate

* Correspondence: glfire@berkeley.edu

1 Department of Molecular and Cell Biology, University of California, Berkeley, CA, 94720, USA

Full list of author information is available at the end of the article adverse birth outcome including spontaneous abortion, still birth, low birth weight and birth length reduction among pregnant women who consumed betel quid during pregnancy $[3,4]$. The meconium, urine and cord serum of newborns whose mother chewed betelquid during pregnancy was found to contain arecoline as detected by mass spectrometric assays[5]. Arecoline and its derivatives are being used clinically to treat Alzheimer's disease based on their use as centrally active muscarinic agents [6]. 
The mechanism of arecoline mediated carcinogenesis in the oral cavity is not fully understood. However, there are reports which indicate that arecoline induces immunodepression, hepatotoxicity and depression of natural antioxidants such as superoxide dismutase, catalase, reduced glutathione and glutathione-s-transferase that are known to neutralize reactive oxygen species in mice [7]. Arecoline has also been found to elicit mutagenicity, genotoxicity, cytotoxicity and chromosomal aberration in different biological systems [8], and has been shown to mediate the cell cycle arrest, ROS generation, change in the mitochondrial membrane potentials in oral mucosal fibroblasts and oral KB epithelial cells [9]. Furthermore, arecoline was recently reported to alter metallothionein$1[10]$ and Heme Oxygenase-1 expression [11,12] in clinicopathological profile of oral submucous fibrosis samples. Our earlier study shows that arecoline is metabolized to $\mathrm{N}$-oxide of arecoline in mouse in vivo and human in vitro, which is Flavin monooxygenase-1 dependent $[13,14]$. Thus, exposure to arecoline has pleiotropic responses in a variety of tissue types that together account for its carcinogenic properties.

Relatively little is known about the potential cellular effects of arecoline on plasma membrane associated signaling components in human cancers. Two types of plasma membrane signaling components that can be altered in transformed cells are apical junction proteins involved in regulating cell-cell interactions and members of specific tyrosine kinase receptors. Tight junctions comprise the more apical structure of junctional complexes that restrict solute diffusion along the paracellular space conferring barrier properties to epithelial and endothelial sheets. Loss of normal junctional formation and cell-cell interactions is thought to play an important role in cancer progression due to significant changes in epithelial compartmentalization and the tissue microenvironment. A key component of junctional complexes that regulates tight junction formation is zonula occludens-1 (ZO-1) [15]. Z0-1 is a $220 \mathrm{kDa}$ protein member of the MAGUK (membrane-associated guanylate kinase homologs) gene family that interacts directly with the transmembrane protein occludin, with $\mathrm{ZO}-2$ and with AF- 6 , a target of the ras oncogene, which is involved in acute myeloid leukemia [16]. ZO-1 is an important marker for tight junction integrity, which is disrupted in many intestinal diseases and highly invasive cancer types, and has been shown to be down regulated in poorly differentiated, highly invasive breast cancer cell lines [17]. Immunohistochemical analysis revealed a gradual decrease of ZO-1 protein from normal breast tissue to well differentiate to moderately differentiate to poorly differentiate human breast cancer tissue samples [18].

HER2 is a transmembrane tyrosine kinase receptor that is a member of the epidermal growth factor (EGF) receptor gene family $[19,20]$ that is expressed at high levels in several human cancers including in late stage endometrial carcinomas and other reproductive cancers [20-22]. Expression of the HER2 gene has been extensively studied in a variety of ovarian and breast adenocarcinomas, with most studies correlating HER2 overexpression with a poor prognosis. Steroid hormones can alter the expression of HER2 in these two types of tumors. For example, in human neoplastic mammary cells estrogens inhibit HER2 expression [23], whereas, in ovarian adenocarcinoma cells glucocorticoids exert a stabilizing effect on existing HER2 transcripts [24].

In the present study, we have established in human Ishikawa endometrial cancer cells that arecoline downregulates expression and disrupts the junctional localization of ZO-1 in a process that requires the downregulation of HER2. Our findings implicate a role for HER2 signaling in the arecoline disruption of apical junction organization in human cancer cells, and have uncovered a new cellular link between HER2 and the control of ZO-1 expression and localization.

\section{Methods}

Dulbecco's modified Eagle's medium, fetal bovine serum (FBS), calcium- and magnesium-free phosphate-buffered saline, L-glutamine and trypsin-versene mixtures were purchased from Biowhittaker (Walkersville, MD). Insulin (bovine) and dimethyl sulfoxide (DMSO) were purchased from Sigma Chemical Co. (St Louis, MO). Arecoline hydrobromide was purchased from Aldrich (Milwaukee, WI). The sources of other reagents are either listed below were of the highest purity available. All antibodies were purchased from Santa Cruz Biotechnology (Santa Cruz, CA) and Invitrogen.MG132 and Dexamethasone were purchased from Sigma Chemical Co.

\section{Cell culture}

Ishikawa human endometrial adenocarcinoma cells were obtained from American Type Culture Collection (Manassas, VA). Ishikawa cells were grown in Dulbecco's modified Eagle's medium supplemented with 10\% Fetal bovine Serum, $10 \mu \mathrm{g} / \mathrm{ml}$ bovine insulin and $50 \mathrm{U} / \mathrm{ml}$ penicillin, $50 \mathrm{U} / \mathrm{ml}$ streptomycin and $2 \mathrm{mM}$ Lglutamine. The cells were grown to subconfluency in a humidified air chamber at $37^{\circ} \mathrm{C}$ containing $5 \% \mathrm{CO} 2$. Arecoline $(99.9 \%$ high-performance liquid chromatography grade) was dissolved in appropriate concentrations in DMSO. DMSO was used as vehicle control for all experiments. All the experiments utilized cultured Ishikawa cells in passage 25 to passage 28 .

\section{Western Blot Analysis}

After the indicated treatments, cells were harvested in radioimmune precipitation assay buffer $(150 \mathrm{mM} \mathrm{NaCl}$, 0.5\% deoxycholate, $0.1 \%$ NoNidet-p40 (Nonidet P-40, Flulta Biochemitra, Switzerland), 0.1\% SDS, 50 mM Tris) 
containing protease and phosphatase inhibitors $(50 \mathrm{~g} / \mathrm{ml}$ phenylmethylsulfonyl fluoride, $10 \mathrm{~g} / \mathrm{ml}$ aprotinin, $5 \mathrm{~g} / \mathrm{ml}$ leupeptin,0.1 g/ml NaF, $1 \mathrm{mM}$ dithiothreitol, $0.1 \mathrm{mM}$ sodium orthovanadate, and $0.1 \mathrm{mM}$-glycerol phosphate). These extracts were then quantified using the Lowry Method (Bio-Rad Laboratories, Hercules, CA). Equal amounts of total cellular protein were mixed with loading buffer (25\% glycerol, 0.075\% SDS, $1.25 \mathrm{ml} \beta$-mercaptoethanol,10\% bromphenol blue, $3.13 \% 0.5 \mathrm{M}$ Tris$\mathrm{HCl}$, and $0.4 \%$ SDS (pH 6.8) and fractionated on $10 \%$ polyacrylamide/0.1\% SDS resolving gels by electrophoresis. Spectra Multicolor Broad range Protein Ladder from Fermentas life sciences was used as the molecular weight standard. Proteins were electrically transferred to nitrocellulose membranes (Micron Separations, Inc., Westboro, MA). Equal protein loading was confirmed by Ponceau S staining of blotted membranes. Proteins were blocked for one and half hour at room temperature with Western wash buffer-5\% NFDM (10 mM Tris- $\mathrm{HCl}$ (pH 8.0), $150 \mathrm{mM} \mathrm{NaCl}$, and $0.05 \%$ Tween 20, 5\% nonfat dry milk). Protein blots were subsequently incubated for overnight at 4 degree temperature with antibody in western buffer. The antibodies used were rabbit anti-ZO-1 (Invitrogen); rabbit anti-Claudin-1 (Santa Cruz Biotechnology); rabbit anti-E-cadherin (Santa Cruz Biotechnology); rabbit anti-beta-catenin (Santa Cruz Biotechnology); and rabbit anti-HER2/neu (Santa cruz Biotechnology). The working concentration for all antibodies was $1 \mu \mathrm{l} / \mathrm{ml}$ in Western wash buffer. Immunoreactive proteins were detected after incubation with horseradish peroxidase conjugated secondary antibody diluted to $0.25 \mu \mathrm{l} / \mathrm{ml}$ in Western wash buffer (goat antirabbit IgG and rabbit anti-mouse IgG (Bio-Rad). Blots were treated with ECL western blotting detection reagent (GE healthcare) and detected on the high performance chemiluminescence film (GE healthcare, UK).

\section{Reverse Transcription PCR}

Ishikawa cells were harvested in PBS and total RNA was isolated. RNA was quantified. $5 \mu \mathrm{g}$ of total RNA was subjected to reverse transcription using murine myelogenous leukemia reverse transcriptase with First strand Buffer, random Primer (hexamers), dNTPs. $2 \mu \mathrm{l}$ of cDNA was then subjected to PCR using Platinum Taq, $10 \times$ PCR buffer, and $200 \mu \mathrm{M}$ each dNTP (Invitrogen) along with the following primer sets and conditions: HER2 Forward 5'CCAGCTCTTTGAGGACAACT - 3' and Reverse 5'ATGTCCTTCCACAAAATCGT- 3', and the cycling conditions were 30 seconds at $95^{\circ} \mathrm{C}$ followed by 30 seconds at $52^{\circ} \mathrm{C}$ for annealing and finally 30 seconds at $72^{\circ} \mathrm{C}$ for extension for 26 cycles. ZO-1 Forward 5'-CGAGTTGCAATGGTTAACGGA-3' and Reverse 5' -TCAGGATCAGGACGACTTACTGG- 3 ', and the cycling conditions were 30 seconds at $95^{\circ} \mathrm{C}$ followed by 30 seconds at $55^{\circ} \mathrm{C}$ for annealing and finally 30 seconds at $72^{\circ} \mathrm{C}$ for extension for 26 cycles. GAPDH primers 5'-TGAAGGTCGGAGTCAACGGATTTG-3', GAPDH Reverse: 5'-CATGTGGGCCATGAGGTCCACCAC-3' (Ambion, Austin TX) served as a control, and PCR was performed according to the manufacturer's instructions. The PCR products were run on $1.1 \%$ agarose gels with Ethidium bromide along with a 1-kb plus DNA ladder (Invitrogen).

\section{Indirect Immunofluorescence Assay}

For indirect immunofluorescence assays, cells were grown on two well chamber slides from Nunc (Fisher scientific, Rochester, NY). The cells were fixed with $3.75 \%$ formaldehyde in PBS for 20 min on ice. After three additional washes with PBS, the plasma membrane was permeabilized with $0.1 \%$ Triton $\mathrm{X}-100 ; 10 \mathrm{mM}$ Tris $\mathrm{HCl}$ at PH 7.5, $120 \mathrm{mM} \mathrm{NaCl} ; 25 \mathrm{mM} \mathrm{KCl;} 2 \mathrm{mM}$ EGTA; and 2 mM EDTA for $10 \mathrm{~min}$ at room temperature. Cells were incubated with 3\% Bovine serum albumin (Sigma) in PBS before incubation with primary antibodies. Rabbit antiZO-1 antibody (61-7300 from Invitrogen) and rabbit anti-E-Cadherin (C212 from Santa Cruz Biotechnology) were used at a 1:400 dilution. Secondary Alexa 488 antirabbit (Molecular Probes, Inc., Eugene, OR) were used at a 1:400 dilution. Stained cells were mounted with Vectashield Mounting media containing DAPI (Vector Laboratories, Inc., Burlingame, CA). Stained and mounted cells were then processed with a Zeiss Axioplan epifluorescence microscope (Carl Zeiss, Thornwood, NY).

\section{Transfection of Ishikawa cells}

To generate stably transfected cells, Ishikawa cells at passage number 25, were transfected with either $0.2 \mu \mathrm{g}$ of CMV-neo empty vector or CMV-HER2 (CMV empty vector and CMV-HER2 were generously provided by the laboratory of Dr. Bjeldanes, UC Berkeley, CA, USA), using polyfact (Qiagen, CA) and following the manufacturer's suggested protocol. Cells were fed $24 \mathrm{~h}$ after transfection with DMEM, supplemented with $10 \%$ fetal calf serum, penicillin/streptomycin. The media was replaced with same media containing $0.7 \mathrm{mg} / \mathrm{ml} \mathrm{G} 418$ (neomycin analog, Mediatech, Herndon, VA) to select for transfected cells. Selection media was replaced every 24 hours for a month and surviving cell populations were propagated in selection media. Experimental treatments were not performed in selection media.

\section{Subcellular Fractionation}

The nuclear and nonnuclear subcellular fractions were harvested from cell extracts using the NE-PER Nuclear Cytoplasmic Extraction Reagents (Pierce, Rockford, IL) according to the manufacturer's instruction. The total protein was quantified using Bradford reagents (BioRad). Cell fractions were examined by Western blots as described above. Anti-lamin was used as a marker for nuclear fraction. 


\section{Results}

Effects of Arecoline on expression of the ZO-1 tight junction protein and the HER2 tyrosine kinase receptor

Arecoline has been detected in saliva obtained during betel nut chewing in concentrations up to $140 \mu \mathrm{g} / \mathrm{ml}$, corresponding to $0.9 \mathrm{mM}$. Arecoline in the millimolar concentration range is thought to participate in the initiation and/or progression of cellular changes during the longterm effects of betel nut chewing [25]. Therefore, to examine the potential effects of arecoline on expression of the ZO-1 tight junction protein and HER2 member of the EGF receptor gene family, cultured human Ishikawas endometrial cancer cells were treated with concentrations of arecoline ranging between $0.1 \mathrm{mM}$ and $0.5 \mathrm{mM}$ and the production of ZO-1 and HER2 protein determined by western blot analysis. The Ishikawa cells were treated for 24 and $48 \mathrm{hr}$ with each arecoline concentration and compared to a DMSO vehicle treated control (0
$\mathrm{mM}$ arecoline). As shown in Figure 1A, arecoline treatment down-regulated production of both $\mathrm{ZO}-1$ and HER2 protein that was observed within 24 hours of treatment at $0.3 \mathrm{mM}$ arecoline. Under the conditions of this experiment, there were no observed changes in actin production, which also serves as a gel loading control. In most of our study, we employed $0.3 \mathrm{mM}$ arecoline, which induces the maximum effect on ZO-1 and HER2 expression without causing apoptosis.

To determine if the arecoline-induced loss of HER2 and $\mathrm{ZO}-1$ protein was due to ubiquitin-26 $\mathrm{S}$ proteasome mediated degradation, Ishikawa cells were treated with or without $0.3 \mathrm{mM}$ arecoline for $24 \mathrm{hr}$ and $48 \mathrm{hr}$ in the presence or absence of MG132, an inhibitor of proteasome peptidase enzymatic activity. As shown in Figure 1B, western blot analysis indicated that the downregulation of both ZO-1 and HER2 protein strongly occurs in the

A

$24 \mathrm{hr}$

$48 \mathrm{hr}$

[Arecoline], $\mathrm{mM}$


Figure 1 Effects of arecoline on expression of ZO-1 and HER2 protein in Ishikawa cells. (A) Subconfluent cultures of Ishikawa cells were treated with DMSO (vehicle control), $0.1 \mathrm{mM}, 0.3 \mathrm{mM}$ or $0.5 \mathrm{mM}$ arecoline for 24 and $48 \mathrm{hrs}$, and total cell extracts were fractionated in SDS polyacrylamide gels. The arecoline regulation of ZO-1 and HER2 protein production was determined by western blot analysis and compared to the levels of actin protein; (B) To determine if the arecoline mediated downregulation of ZO-1 and HER2 protein was due to induced ubiquitination and $26 \mathrm{~S}$ proteasome mediated degradation, Ishikawa cells were treated with or without $0.3 \mathrm{mM}$ arecoline for $48 \mathrm{hrs}$ and in the presence or absence of MG132, an inhibitor of proteasome peptidase enzymatic activity. Total cell extracts were analyzed by Western blotting for ZO-1 and HER2 in comparison to actin. 


\begin{tabular}{|c|c|c|c|c|c|}
\hline [Arecoline], mM & 0 & 0.1 & 0.3 & 0.5 & $\mathrm{mF}$ \\
\hline & 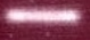 & nin & - & 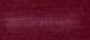 & HER2 \\
\hline & $=$ & - & 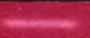 & 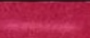 & ZO-1 \\
\hline
\end{tabular}

Figure 2 Arecoline downregulates of ZO-1 and HER2 transcripts in Ishikawa cells. Ishikawa cells were treated with the DMSO vehicle control, $0.1 \mathrm{mM}, 0.3 \mathrm{mM}$ or $0.5 \mathrm{mM}$ arecoline for 48 hrs and total RNA was isolated and quantified by RT-PCR analysis. Oligonucleotides specific for ZO-1, HER2 or GAPDH were used to generate specific RT-PCR fragments that were fractionated in agarose gels. The transcript specific bands were visualized by ethidium bromide staining.

presence of MG132, suggesting that the loss of both proteins are not due to proteasomal degradation.

\section{Arecoline Downregulates ZO-1 and HER 2 Transcript Levels} in Ishikawa endometrial cancer cells

To uncover the cellular processes regulated by arecoline that leads to the down-regulation of $\mathrm{ZO}-1$ and HER2 protein levels, Ishikawa cells were cultured in the presence of varying concentrations of arecoline for 48 hours, and the levels of HER2 and ZO-1 transcripts were compared with DMSO vehicle treated control cells. As shown in Figure 2, reverse transcription-PCR analysis revealed that arecoline treatment downregulates expression of HER2 and ZO-1 transcripts after 48 hours in a dose dependent manner. Maximum effects were observed after the cells were treated with $0.5 \mathrm{mM}$ arecoline for $48 \mathrm{hr}$, although signaificant effects were observed in the presence of 0.3 $\mathrm{mM}$ arecoline. GAPDH transcript levels remained unchanged and were used as gel loading controls. The arecoline mediated loss of ZO- 1 and HER2 transcripts accounts for the down-regulation of the corresponding protein levels.

\section{Effects of Arecoline on expression of Tight Junction and Adherens Junction proteins}

Both tight junctions and adherens junction are comprised of distinct protein complexes [15], and therefore the potential effects of arecoline were assessed on expression of several tight junction and adherens junction proteins. Ishikawa cells were treated with or without $0.3 \mathrm{mM}$ and $0.5 \mathrm{mM}$ arecoline for 48 hours, and the level of the ZO-1 and Claudin-1 tight junction proteins and the E-cadherin and beta-catenin adherens junction proteins were analyzed by western blots. Actin proteins levels were used as a constitutive control protein for comparison to the apical junction proteins. As shown in Figure 3, under conditions

\section{Tight Junction proteins}
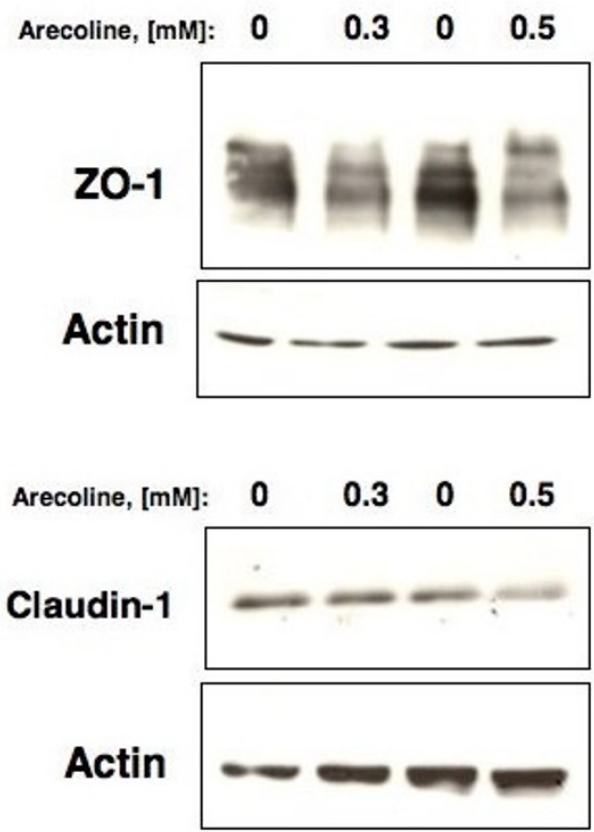

\section{Adherens Junction proteins}
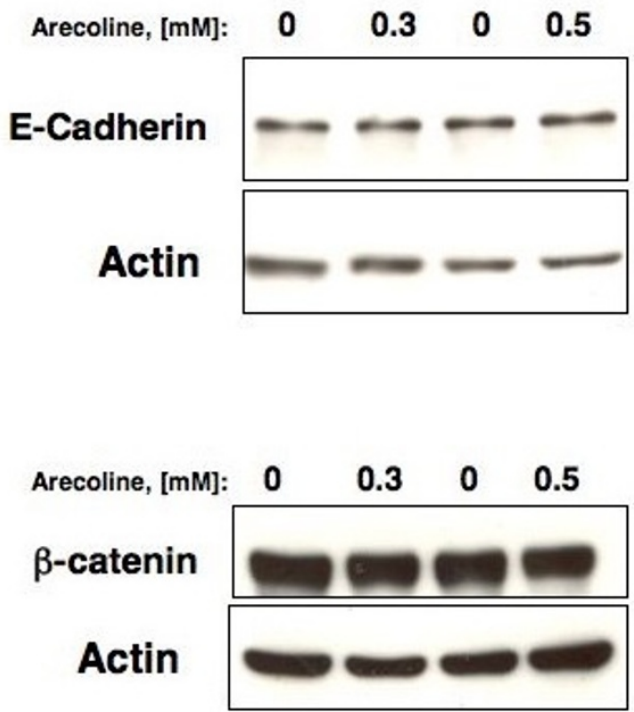

Figure 3 Arecoline effects on expression of tight junction and adherens junction proteins in Ishikawa cells. Ishikawa cells were treated with DMSO (vehicle control) or with either $0.3 \mathrm{mM}$ or $0.5 \mathrm{mM}$ arecoline for $48 \mathrm{hrs}$, and total cell extracts were fractionated in SDS polyacrylamide gels. The production of ZO-1, Claudin-1, E-cadherin, and beta-catenin protein was determined by western blot analysis and compared to the levels of actin protein. 
in which arecoline strongly down-regulated $\mathrm{ZO}-1$ protein levels, this alkaloid also down-regulated the Claudin-1 protein, which is also a component of the tight junction. Arecoline had no significant effects on the protein levels of either E-cadherin or beta-catenin, which are both critical components of adherens junctions. Thus, expression of tight junction proteins appears to be significantly more sensitive to the disruptive effects of arecoline compared to adherens junction proteins.

\section{Arecoline disruption of the localization of ZO-1 protein}

In the apical junction, $\mathrm{ZO}-1$ characteristically forms a continuous band at the periphery of well-differentiated, confluent, polarized epithelial cells. The localization of ZO-1 changes dramatically according to the confluency of cells, with low confluent cells having an accumulation of nuclear ZO-1 localization and high confluent cells having $\mathrm{ZO}-1$ locate at the plasma membrane. Nuclear local- ization of ZO-1 has also been detected in many cell types [26]. Indirect immunofluorescence was utilized to assess the potential effects of arecoline on ZO-1 localization in Ishikawa cells treated with various concentrations of arecoline for 24 hours and 48 hours. As shown in Figure 4, arecoline treatment disrupted the characteristically continuous bands of ZO-1 staining around the apices of Ishikawa cells. Treatment with $0.3 \mathrm{mM}$ arecoline induced a near maximal effect on ZO-1 localization at both 24 hours and 48 hours of incubation. The overall ZO-1 staining pattern in arecoline treated cells was highly disorganized, which is indicative of a disruption of the apical junctional complex.

The effect of arecoline on the ZO-1 cellular staining pattern was examined in the context of the cellular staining pattern of the adherens junction protein E-cadherin. Ishikawa cells were treated with or without $0.3 \mathrm{mM}$ and $0.5 \mathrm{mM}$ arecoline for 48 hours and the E-cadherin stain-

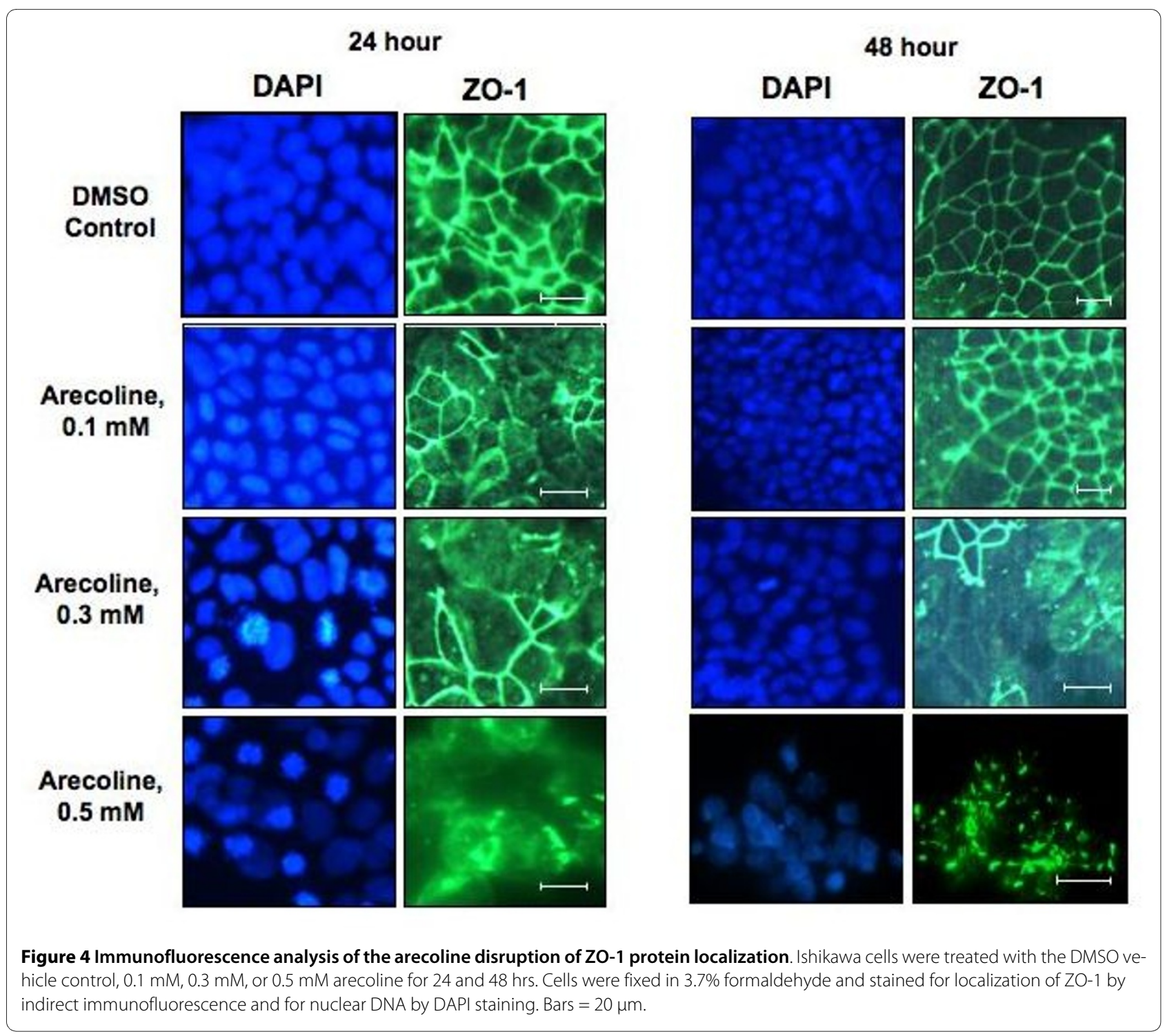


ing pattern analyzed by indirect immunofluorescence. As shown in figure 5 , at the lower arecoline concentration of $0.3 \mathrm{mM}$, the overall E-cadherin staining pattern remained mostly intact and highly organized to the cell periphery. At this alkaloid concentration, the ZO-1 staining pattern was mostly disorganized (shown in Figure 4). At the higher arecoline concentration $(0.5 \mathrm{mM})$, E-cadherin shows a generally similar degree of disorganization as that observed for ZO-1 (Figure 5 compared to Figure 4).

To further characterize the effects of arecoline on the subcellular distribution of ZO-1, the nuclear and cytoplasmic/membrane fractions were biochemically separated after treatment of Ishikawa cells for $48 \mathrm{hr}$ with 0 $\mathrm{mM}$ (vehicle treated control), $0.1 \mathrm{mM}, 0.3 \mathrm{mM}$ or $0.5 \mathrm{mM}$ arecoline. ZO-1 exists as two isoforms depending upon the presence or absence of an 80 amino acid $\mathrm{N}$-terminal domain denoted as ZO-1 $\alpha^{+}$and ZO-1 $\alpha^{-}$[15]. The proportion of each isoform is characteristic of particular cell types [15]. As shown in Figure 6, the nuclear fraction of Ishikawa cells was found to contain only $\mathrm{ZO}-1 \alpha^{+}$ whereas, the cytoplasmic/membrane fraction contains both ZO- $1 \alpha^{+}$and ZO-1 $\alpha^{-}$. Arecoline treatment downregulated the expression of both isoforms from the nuclear as well as cytoplasmic/membrane subcellular fractions compared to the DMSO vehicle treated control cells (0 $\mathrm{mM}$ arecoline). HER2 can be imported into the nucleus of certain cell types through a nuclear localization signal mediated mechanism [27]. Our results also revealed that HER2 is localized in both the cytomplas$\mathrm{mic} / \mathrm{membrane}$ and the nuclear fractions of the Ishikawa cells, and the treatment with arecoline down-regulates HER2 protein levels from both subcellular fractions (Figure 6).

\section{Expression of exogenous HER2 prevents the arecoline down-regulation of ZO-1 and overrides the disruption of ZO-1 localizalization in Ishikawa cells}

To functionally test the link between the arecoline downregulated expression of ZO-1 and HER2, Ishikawa cells were transfected with the CMV-HER2 expression plasmid or with the control CMV-neo empty vector plasmids. The transfection competent cells were stably selected for 30 days in G418. Western blot analysis revealed that CMV-HER2 transfected cells expressed significantly higher levels of HER2 protein compared to the control transfected cells (Figure 7A). Both the CMV-HER2 transfected and the CMV-neo transfected Ishikawa cells were treated with $0.3 \mathrm{mM}$ arecoline for 48 hours, and the production of $\mathrm{ZO}-1$ protein was examine by western blot analysis. As shown in figure $7 \mathrm{~B}$, expression of exogenous HER2 ablated the arecoline down-regulation of ZO-1 protein, which demonstrates a strong functional connection between the level of HER2 protein and ability of arecoline to attenuate ZO-1 expression.

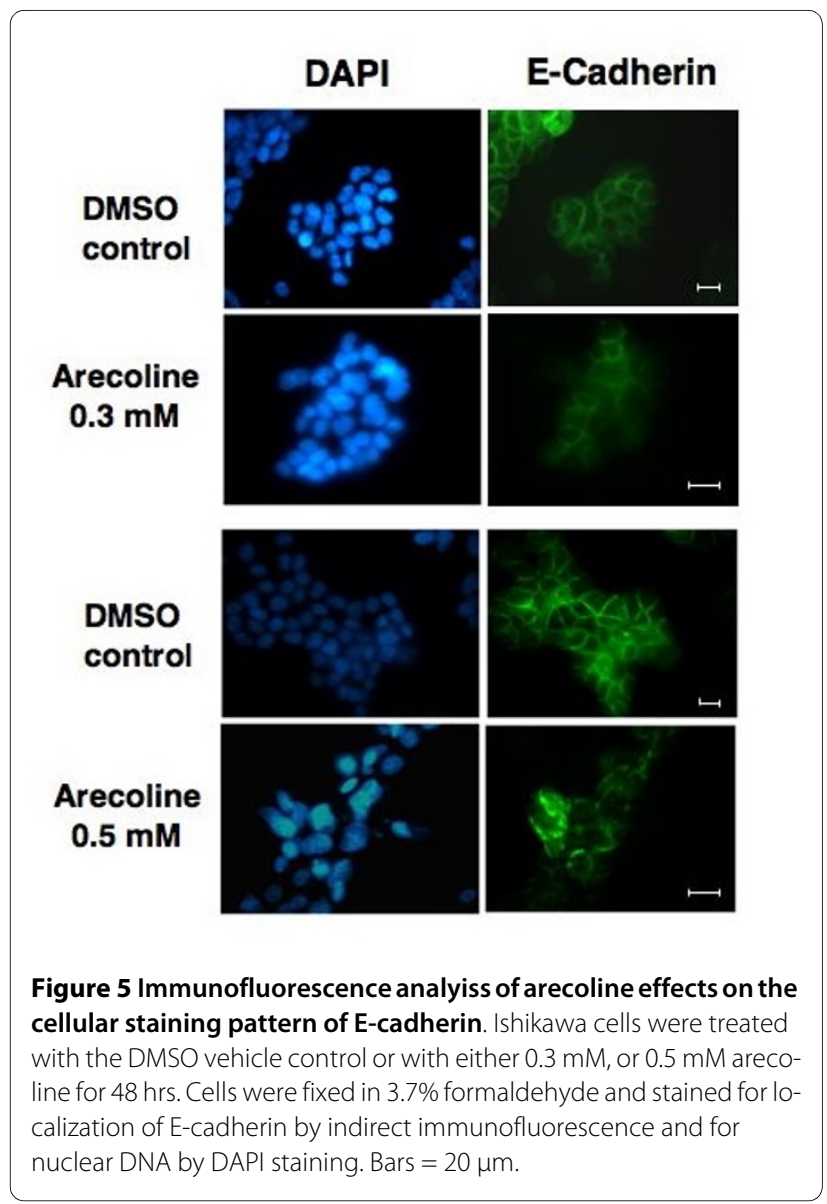

Indirect immunofluorescence was employed to examine the potential effects of exogenous HER2 expression on the arecoline disruption of $\mathrm{ZO}-1$ localization. As shown in Figure 8, in CMV-HER2 transfected Ishikawa cells, expression of exogenous HER2 completely prevented the arecoline-mediated disruption of $\mathrm{ZO}-1$ localization to the cell periphery. The ZO- 1 staining pattern in CMV-HER2 cells treated with arecoline for 24 hours or 48 hours was virtually identical to DMSO vehicle treated control cells (Figure 8, upper panels). As expected, in the CMV-neo control transfected cells, arecoline treatment induced a significant disruption of $\mathrm{ZO}-1$ localization (Figure 8, lower panels), with the staining pattern indicative of a disorganized junctional complex. It is important to point that the $\mathrm{ZO}-1$ staining pattern in arecoline treated and untreated CMV-neo transfected cells is essentially the same as that observed in untransfected cells (Figure 4) showing that the transfection per se had no unusual effect on the cell phenotype.

\section{Dexamethasone treatment overrides the arecoline} disruption of ZO-1 localization in Ishikawa cells

It has been previously shown that treatment with the synthetic glucocorticoid dexamethasone strongly stimulates 


\section{membranes}

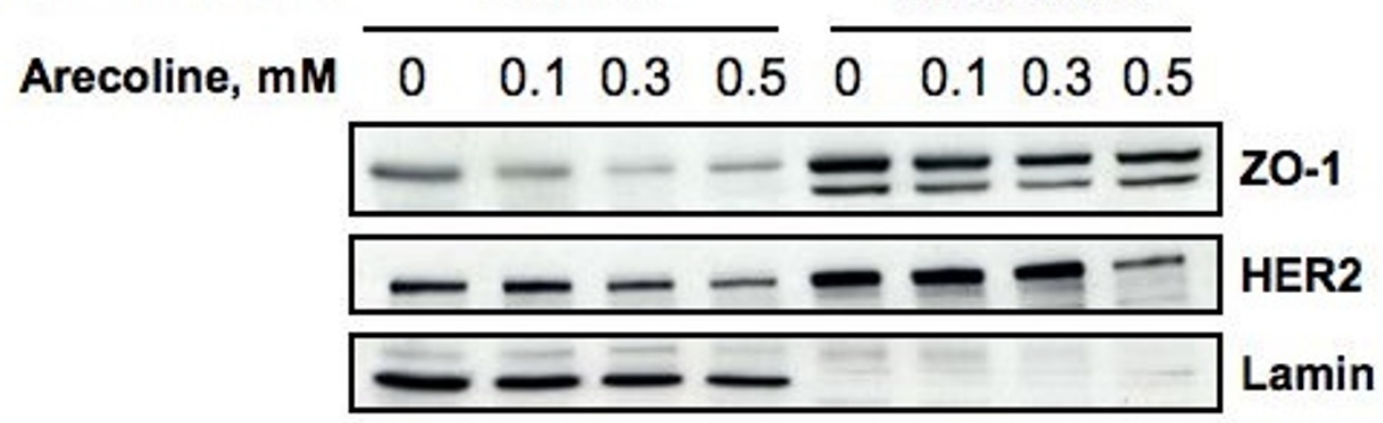

Figure 6 Arecoline down regulates the level of ZO-1 and HER2 proteins in both the Cytoplasmic/membrane as well as nuclear fractions of Ishikawa cells. The Ishikawa cells were treated with the DMSO vehicle control, $0.1 \mathrm{mM}, 0.3 \mathrm{mM}$, or $0.5 \mathrm{mM}$ arecoline for 48 hours. The nuclear and cytoplasmic/memebrane fraction was separated biochemically by differential centrifugation, and distribution of ZO-1 and HER2 was evaluated by western blot analysis in comparison to the lamin nuclear marker protein.

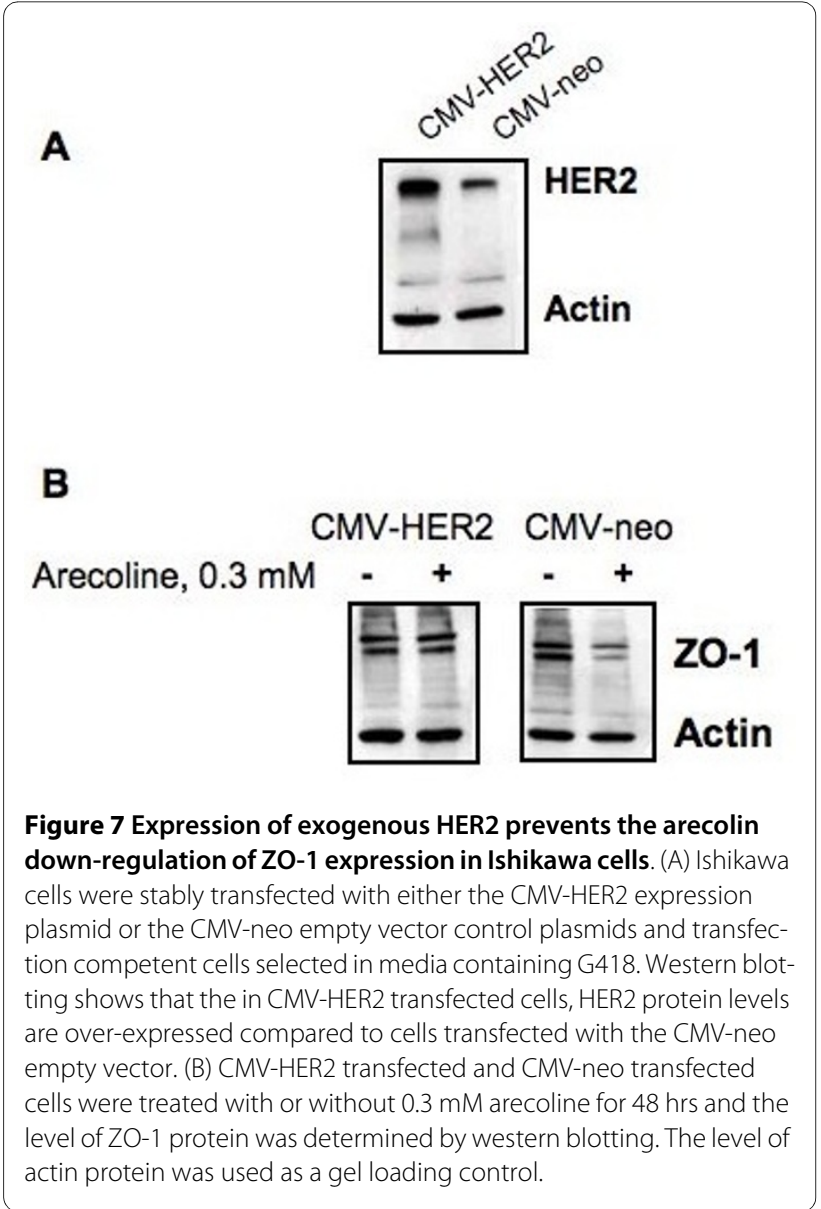

expression of HER2 in Ishikawa endometrial cancer cells and in human epithelial ovarian carcinoma cell lines [24]. Our previous study demonstrated that dexamethasone induces tight junctional complex formation in the rat Con8 mammary epithelial tumor cell line [28]. Together, these observations suggest that dexamethasone treatment may provide a hormonal tool to functionally assess the arecoline effects on the dynamics of ZO-1 localization. Ishikawa cells were treated with or without $1 \mu \mathrm{M}$ dexamethasone or $10 \mu \mathrm{M}$ dexamethasone and apical junction localization of ZO-1 was visualized using indirect immunofluorescence. As shown in Figure 9, ZO-1 staining revealed that in dexamethasone treated cells, the apical junction complex was somewhat more organized compared to the DMSO treated cells. In presence of $1 \mu \mathrm{M}$ dexamethasone, the disruptive effects of $0.3 \mathrm{mM}$ arecoline on ZO-1 localization were partially restored (Figure 9). At $10 \mu \mathrm{M}$ dexamethasone, the disruptive effects of 0.3 $\mathrm{mM}$ arecoline was completely ablated as the ZO-1 staining pattern in cells treated with dexamethasone and arecoline was quite similar to that observed in the DMSO vehicle treated control cells (Figure 9, top versus bottom panels).

\section{Discussion}

We have established that arecoline has profound effects on plasma membrane associated signaling proteins in the human endometrial Ishikawa cell line. Arecoline was shown to coordinately down regulate the expression and disrupt localization of the ZO-1 tight junction component of the apical junction complex as well as decrease 


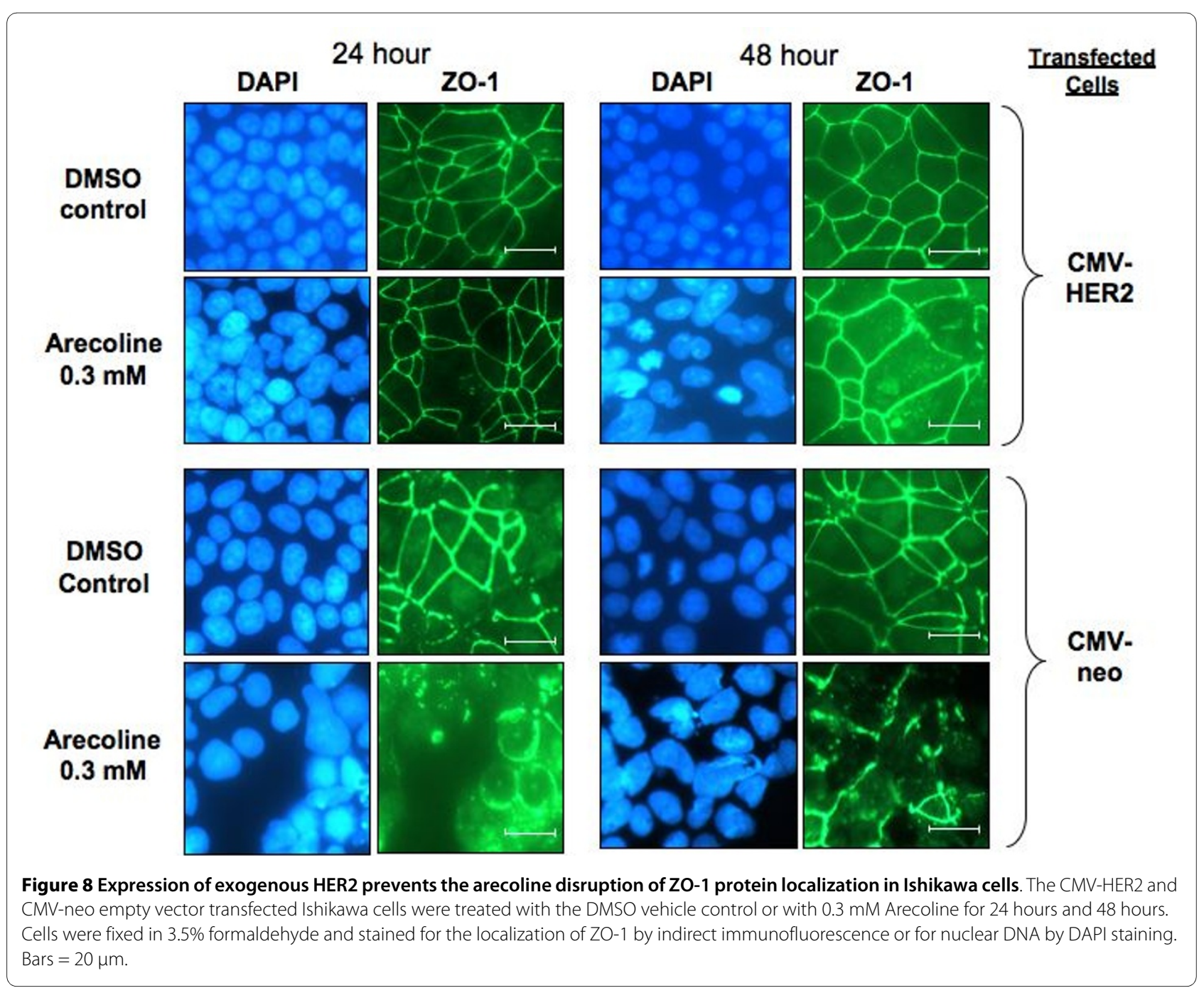

expression of the HER2 member of the epidermal growth factor receptor gene family. Our studies have uncovered a functional link between the arecoline down regulation of ZO-1 and HER2 because expression of exogenous HER2 completely prevents the ability of arecoline to disrupt ZO-1 expression and localization to the cell periphery. Furthermore, treatment with dexamethasone, a synthetic glucocorticoid that has been shown to upregulate HER2 expression in Ishikawa endometrial cancer cells [24], also overrides the disruptive effects of arecoline on ZO-1 localization. A functional connection between HER2 levels and the control of ZO-1 localization or expression has not been previously observed in human cancer cells.

HER2 plays an important role in the regulation of cell growth, differentiation and survival through its heterodimerization with other members of the EGF receptor gene family [29]. A variety of cell and tissue types expresses HER2 [29], and a number of human cancers frequently over-express HER2 due to gene amplification including many reproductive cancers [21,30-33] as well as lung, gastric and oral cancers [34-39]. Patients with HER2overexpressing breast or ovarian cancer have significantly shorter overall survival rate and time of relapse relative to patients with tumors without HER2 overexpression $[21,30,31]$. Because of HER2 overexpression in many cancers, its accessible location on the cell surface and its role in carcinogenesis HER2 has been under intensive scrutiny as a therapeutic target. HER2 is expressed at low levels in normal tissue compared to cancer cells [40], which suggests the existence of a suitable therapeutic window to minimize damage to normal cells but still be able to target HER2-positive cancers by inhibiting either HER2 protein function or expression [41].

Studies examining ZO-1 protein stability have uncovered a range of ZO-1 protein half lives (ranging between 5 and 20 hours) that can differ depending on the cell type and cell cultured conditions such as cell confluency $[42,43]$. Although in many systems, regulated changes in the stability of ZO-1 protein can potentially play a role in its cellular regulation, we have shown that in Ishikawa 


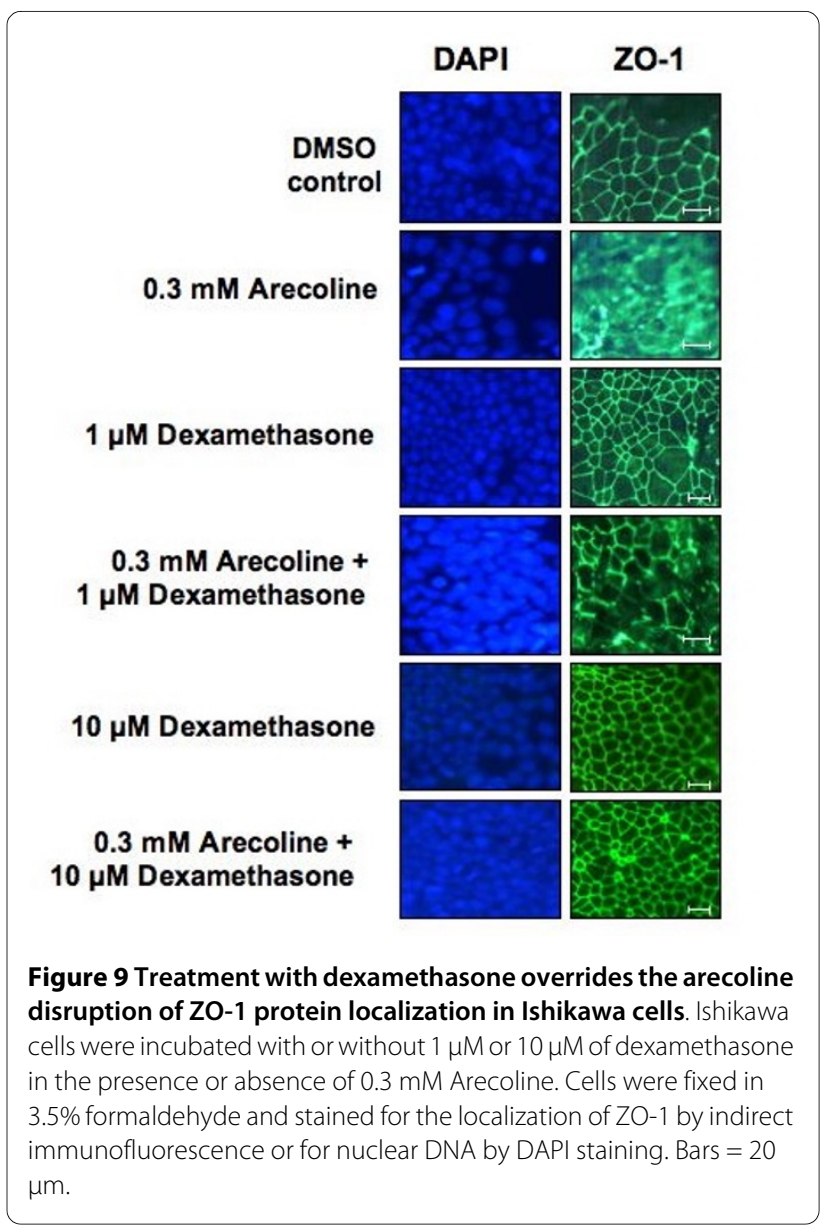

endometrial cancer cells, the loss of $\mathrm{ZO}-1$ protein is accounted for an a corresponding loss in ZO-1 transcript levels. We have also determined that arecoline concurrently reduces HER2 protein and transcript expression along with that of ZO-1 expression, and that ectopic expression of HER2 reverses the arecoline down regulation of ZO-1. We are currently attempting to establish the precise mechanism by which the arecoline-mediated loss of HER2 levels leads to these effects on ZO-1 utilization. In this regard, is thought that over-expression of HER2 in human cancer cells due to amplification enhances the preferential binding of the low-affinity arm of ligands to HER2 resulting in increased intracellular signaling [44] that could ultimately lead to the control of $\mathrm{ZO}-1$ and potential regulation of ZO-1 mediated cell-cell interactions. Interestingly, a transcriptional factor that binds to the $\mathrm{SH} 3$ domain of ZO-1 (ZONAB, ZO-1-associated nucleic acid binding protein) was shown in MDCK cells to functionally interact with the nuclear form of ZO-1 to modulate expression of HER2 in a cell density dependent manner [45]. This study, in combination with our results, suggests that the expression and cellular use of ZO-1 and HER2 may be linked thorough a mutual feedback system in certain human cancer cells. Because dexamethasone, a synthetic glucocorticoid, regulates the transcription of glucocorticoid receptor target genes and overrides the effects of arecoline on ZO-1 localization, it is tempting to speculate that this steroid hormone alters the transcriptional dynamics of HER2 in this system and thereby stabilizes ZO-1 expression and localization.

\section{Conclusion}

Arecoline induced cellular changes in the oral cavity in areca nut chewers leading to oral precancerous lesions may be due to disrupted expression and junctional localization of the ZO-1 tight junctional protein. Furthermore, we have established that the ability of arecoline to control $\mathrm{ZO}-1$ in human Ishikawa cancer cells requires the coordinate down regulation of the HER2 member of the EGF receptor gene family. This observation represents a previously unknown functional connection between HER2 expression and the cellular accessibility of ZO-1. Thus, the physiological control of HER2 expression in human tissues may play a direct role in the susceptibility of humans to the carcinogenic effects of arecoline.

\section{Authors' contributions}

SG and GLF jointly designed the experiments and wrote the paper. SG completed all of the ZO-1 protein experiments. SNS helped in designing the experiments and KMP conducted the RT-PCR study and the western blots and indirect immunofluorescence of the adherens junction proteins. All authors read and approved the final manuscript.

\section{Acknowledgements}

The research described in this paper was supported by National Institute of Health Grant DK-42799 (to G.L.F.) and by Indo-US Science and Technology Forum Fellowship by Department of Science and Technology, Government of India, awarded to S. G. (Ref:IUSSTF/Fellowship/2007-08/8-2008). We are thankful to Dr. Crystal Marconett and Dr. Ida Aronchik for helpful discussion. Technical support of Bhumika Kapadia and Kelvin Tran in the Firestone Lab during the course of study is thankfully acknowledged.

\section{Author Details}

1 Department of Molecular and Cell Biology, University of California, Berkeley, CA, 94720, USA and 2Department of Life Science, Assam University, Silchar, Assam-788011, India

Received: 15 December 2009 Accepted: 6 July 2010 Published: 6 July 2010

\section{References}

1. Oakley E, Demaine L, Warnakulasuriya S: Areca (betel) nut chewing habit among high-school children in the Commonwealth of the Northern Mariana Islands (Micronesia). Bulletin of the World Health Organization 2005, 83:656-660.

2. Toyoshima K, Semba K, Akiyama T, Ikawa S, Yamamoto T: The c-erbB-2 gene encodes a receptor-like protein with tyrosine kinase activity. Cold Spring Harbor Symposia on Quantitative Biology 1986, 51:977-982.

3. Yang MS, Chang FT, Chen SS, Lee CH, Ko YC: Betel quid chewing and risk of adverse pregnancy outcomes among aborigines in southern Taiwan. Public Health 1999, 113:189-192.

4. Yang MS, Lee CH, Chang SJ, Chung TC, Tsai EM, Ko AM, Ko YC: The effect of maternal betel quid exposure during pregnancy on adverse birth outcomes among aborigines in Taiwan. Drug and Alcohol Dependence 2008, 95:134-139.

5. Pichini S, Pellegrini M, Pacifici R, Marchei E, Murillo J, Puig C, Vall O, GarciaAlgar O: Quantification of arecoline (areca nut alkaloid) in neonatal biological matrices by high-performance liquid chromatography/ 
electrospray quadrupole mass spectrometry. Rapid Commun Mass Spectrom 2003, 17:1958-1964

6. Christie JE, Shering A, Ferguson J, Glen Al: Physostigmine and arecoline: effects of intravenous infusions in Alzheimer presenile dementia. $\mathrm{Br}$ J Psychiatry 1981, 138:46-50

7. Dasgupta R, Saha I, Pal S, Bhattacharyya A, Sa G, Nag TC, Das T, Maiti BR: Immunosuppression, hepatotoxicity and depression of antioxidant status by arecoline in albino mice. Toxicology 2006, 227:94-104.

8. Jeng JH, Chang MC, Hahn LJ: Role of areca nut in betel quid-associated chemical carcinogenesis: current awareness and future perspectives. Oral Oncology 2001, 37:477-492.

9. Chang MC, Ho YS, Lee PH, Chan CP, Lee JJ, Hahn LJ, Wang YJ, Jeng JH: Areca nut extract and arecoline induced the cell cycle arrest but not apoptosis of cultured oral KB epithelial cells: association of glutathione, reactive oxygen species and mitochondrial membrane potential. Carcinogenesis 2001, 22:1527-1535.

10. Lee SS, Yang SF, Tsai CH, Chou MC, Chou MY, Chang YC: Upregulation of heme oxygenase-1 expression in areca-quid-chewing-associated oral squamous cell carcinoma. Journal of the Formosan Medical Association = Taiwan yi zhi 2008, 107:355-363.

11. Lee SS, Tsai CH, Ho YC, Chang YC: The upregulation of heat shock protein 70 expression in areca quid chewing-associated oral squamous cell carcinomas. Oral Oncology 2008, 44:884-890.

12. Lee SS, Yang SF, Ho YC, Tsai CH, Chang YC: The upregulation of metallothionein-1 expression in areca quid chewing-associated oral squamous cell carcinomas. Oral Oncology 2008, 44:180-186.

13. Giri S, Idle JR, Chen C, Zabriskie TM, Krausz KW, Gonzalez FJ: A metabolomic approach to the metabolism of the areca nut alkaloids arecoline and arecaidine in the mouse. Chemical Research in Toxicology 2006, 19:818-827.

14. Giri S, Krausz KW, Idle JR, Gonzalez FJ: The metabolomics of (+/-)arecoline 1-oxide in the mouse and its formation by human flavincontaining monooxygenases. Biochemical Pharmacology 2007 , 73:561-573.

15. Ebnet $\mathrm{K}$ : Organization of multiprotein complexes at cell-cell junctions. Histochem Cell Biol 2008, 130:1-20.

16. Yamamoto T, Harada N, Kano K, Taya S, Canaani E, Matsuura Y, Mizoguch A, Ide C, Kaibuchi K: The Ras target AF-6 interacts with ZO-1 and serves as a peripheral component of tight junctions in epithelial cells. The Journal of Cell Biology 1997, 139:785-795.

17. Sommers CL, Byers SW, Thompson EW, Torri JA, Gelmann EP: Differentiation state and invasiveness of human breast cancer cell lines. Breast Cancer Research and Treatment 1994, 31:325-335.

18. Hoover KB, Liao SY, Bryant PJ: Loss of the tight junction MAGUK ZO-1 in breast cancer: relationship to glandular differentiation and loss of heterozygosity. The American Journal of Pathology 1998, 153:1767-1773.

19. Coussens L, Yang-Feng TL, Liao YC, Chen E, Gray A, McGrath J, Seeburg PH, Libermann TA, Schlessinger J, Francke U, et al.: Tyrosine kinase receptor with extensive homology to EGF receptor shares chromosomal location with neu oncogene. Science (New York, NY) 1985, 230:1132-1139.

20. Yamamoto T, Ikawa S, Akiyama T, Semba K, Nomura N, Miyajima N, Saito T, Toyoshima K: Similarity of protein encoded by the human c-erb-B-2 gene to epidermal growth factor receptor. Nature 1986, 319:230-234.

21. Slamon DJ, Godolphin W, Jones LA, Holt JA, Wong SG, Keith DE, Levin WJ, Stuart SG, Udove J, Ullrich A, et al.: Studies of the HER-2/neu protooncogene in human breast and ovarian cancer. Science 1989, 244:707-712.

22. Kuhn EJ, Kurnot RA, Sesterhenn IA, Chang EH, Moul JW: Expression of the c-erbB-2 (HER-2/neu) oncoprotein in human prostatic carcinoma. The Journal of Urology 1993, 150:1427-1433.

23. De Bortoli M, Dati C, Antoniotti S, Maggiora P, Sapei ML: Hormona regulation of c-erbB-2 oncogene expression in breast cancer cells. The Journal of Steroid Biochemistry and Molecular Biology 1992, 43:21-25.

24. Markogiannakis E, Georgoulias V, Margioris AN, Zoumakis E, Stournaras C, Gravanis A: Estrogens and glucocorticoids induce the expression of cerbB2/NEU receptor in Ishikawa human endometrial cells. Life Sciences 1997, 61:1083-1095

25. Chang YC, Tai KW, Lii CK, Chou LS, Chou MY: Cytopathologic effects of arecoline on human gingival fibroblasts in vitro. Clinical Oral Investigations 1999, 3:25-29.
26. Gottardi CJ, Arpin M, Fanning AS, Louvard D: The junction-associated protein, zonula occludens-1, localizes to the nucleus before the maturation and during the remodeling of cell-cell contacts. Proc Nat Acad Sci USA 1996, 93:10779-10784.

27. Chen $Q Q$, Chen $X Y$, Jiang YY, Liu J: Identification of novel nuclear localization signal within the ErbB-2 protein. Cell Research 2005 15:504-510.

28. Failor KL, Desyatnikov Y, Finger LA, Firestone GL: Glucocorticoid-induced degradation of glycogen synthase kinase-3 protein is triggered by serum- and glucocorticoid-induced protein kinase and Akt signaling and controls beta-catenin dynamics and tight junction formation in mammary epithelial tumor cells. Molecular Endocrinology 2007, 21:2403-2415

29. Hynes NE, Stern DF: The biology of erbB-2/neu/HER-2 and its role in cancer. Biochimica et Biophysica Acta 1994, 1198:165-184

30. Berchuck A, Rodriguez G, Kamel A, Soper JT, Clarke-Pearson DL, Bast RC: Expression of epidermal growth factor receptor and HER-2/neu in normal and neoplastic cervix, vulva, and vagina. Obstetrics and Gynecology 1990, 76:381-387.

31. Slamon DJ, Clark GM, Wong SG, Levin WJ, Ullrich A, McGuire WL: Human breast cancer: correlation of relapse and survival with amplification of the HER-2/neu oncogene. Science 1987, 235:177-182.

32. McCann AH, Dervan PA, O'Regan M, Codd MB, Gullick WJ, Tobin BM, Carney DN: Prognostic significance of c-erbB-2 and estrogen receptor status in human breast cancer. Cancer Research 1991, 51:3296-3303.

33. van de Vijver M, van de Bersselaar R, Devilee P, Cornelisse C, Peterse J, Nusse R: Amplification of the neu (c-erbB-2) oncogene in human mammmary tumors is relatively frequent and is often accompanied by amplification of the linked c-erbA oncogene. Molecular and Cellular Biology 1987, 7:2019-2023.

34. Hou L, Shi D, Tu SM, Zhang HZ, Hung MC, Ling D: Oral cancer progression and c-erbB-2/neu proto-oncogene expression. Cancer Letters 1992, 65:215-220.

35. Schneider PM, Hung MC, Chiocca SM, Manning J, Zhao XY, Fang K, Roth JA: Differential expression of the c-erbB-2 gene in human small cell and non-small cell lung cancer. Cancer Research 1989, 49:4968-4971.

36. Weiner DB, Nordberg J, Robinson R, Nowell PC, Gazdar A, Greene MI, Williams WV, Cohen JA, Kern JA: Expression of the neu gene-encoded protein (P185neu) in human non-small cell carcinomas of the lung. Cancer Research 1990, 50:421-425.

37. Yokota J, Yamamoto T, Miyajima N, Toyoshima K, Nomura N, Sakamoto H, Yoshida T, Terada M, Sugimura T: Genetic alterations of the c-erbB-2 oncogene occur frequently in tubular adenocarcinoma of the stomach and are often accompanied by amplification of the $v$-erbA homologue. Oncogene 1988, 2:283-287.

38. Yoshida K, Tsuda T, Matsumura T, Tsujino T, Hattori T, Ito H, Tahara E: Amplification of epidermal growth factor receptor (EGFR) gene and oncogenes in human gastric carcinomas. Virchows Archiv 1989, 57:285-290

39. Xia W, Lau YK, Zhang HZ, Liu AR, Li L, Kiyokawa N, Clayman GL, Katz RL, Hung MC: Strong correlation between c-erbB-2 overexpression and overall survival of patients with oral squamous cell carcinoma. Clin Cancer Res 1997, 3:3-9.

40. De Potter CR, Schelfhout AM, Verbeeck P, Lakhani SR, Brunken R, Schroeter CA, Van den Tweel JG, Schauer AJ, Sloane JP: neu overexpression correlates with extent of disease in large cell ductal carcinoma in situ of the breast. Human Pathology 1995, 26:601-606.

41. Sliwkowski MX, Schaefer G, Akita RW, Lofgren JA, Fitzpatrick VD, Nuijens A, Fendly BM, Cerione RA, Vandlen RL, Carraway KL: Coexpression of erbB2 and erbB3 proteins reconstitutes a high affinity receptor for heregulin. The Journal of Biological Chemistry 1994, 269:14661-14665.

42. Gumbiner B, Lowenkopt T, Apatria D: Identification of a 160-kDa polypeptide that binds to the tight junction protein ZO-1. Proc Nat Acad Sci USA 1991, 88:3460-3464

43. Chen Y-H, Lu Q, Schneeberger EE, Goodenough DA: Restoration of tight junction structure and barrier function by down-regulation of the mitogen-activated protein kinase pathway in ras-transformed MadinDarby canine kidney cells. Molecular Biology of the Cell 2000, 11:849-862.

44. Tzahar E, Yarden Y: The ErbB-2/HER2 oncogenic receptor of adenocarcinomas: from orphanhood to multiple stromal ligands. Biochimica et Biophysica Acta 1998, 1377:M25-37. 
45. Balda MS, Matter K: The tight junction protein ZO- 1 and an interacting transcription factor regulate ErbB-2 expression. The EMBO Journal 2000, 19:2024-2033.

doi: $10.1186 / 1471-2121-11-53$

Cite this article as: Giri et al., Arecoline induced disruption of expression and localization of the tight junctional protein ZO-1 is dependent on the HER 2 expression in human endometrial Ishikawa cells BMC Cell Biology 2010, 11:53

Submit your next manuscript to BioMed Central and take full advantage of:

- Convenient online submission

- Thorough peer review

- No space constraints or color figure charges

- Immediate publication on acceptance

- Inclusion in PubMed, CAS, Scopus and Google Scholar

- Research which is freely available for redistribution

Submit your manuscript at www.biomedcentral.com/submit 